\title{
HUBUNGAN MOTIVASI DAN SEMANGAT KERJA DALAM MENINGKATKAN KINERJA KARYAWAN
}

\author{
Siska Inggriani \\ Universitas Negeri Padang \\ Indonesia \\ E-mail : siskainggriani3008@gmail.com
}

\author{
Ermita \\ Universitas Negeri Padang \\ Indonesia \\ E.mail : ermita@fip.unp
}

\begin{abstract}
Abstrak
Motivation and enthusiasm of a person in the workplace is one important factor to improve employee performance in a company. The motivation and high morale of a person can carry out their duties and responsibilities to the maximum extent possible, with high motivation and enthusiasm from one's employees to have a positive impact on the progress and development of the company going forward. If the higher the motivation and enthusiasm of employee work, the better the performance of employees in a company. Data collection techniques used in this journal are the techniques of collecting literature study data by collecting all relevant sources from books, journals, articles and other sources. The purpose of writing this journal is to determine the relationship of motivation and enthusiasm in improving employee performance in a company.
\end{abstract}

Keyword Motivasi kerja, semangat kerja,kinerja karyawan

\section{PENDAHULUAN}

Manajemen modern berargumen bahwa tingkah laku manusia didorong oleh motif-motif tertentu, dan perbuatan/ bekerja akan berhasil bila didasarkan pada motivasi yang ada pada diri seseorang. Bawahan atau staf dapat dipaksa untuk mengerjakan sesuatu pekerjaan, tetapi ia tidak dapat dipaksa untuk memahami setiap pekerjaan itu seperti yang diharapkan. Manajer dapat melakukan kegiatan atau tugas kepada bawahannya, tetapi tidak mungkin memaksanya untuk bekerja dalam arti yang sesungguhnya. Hal inilah yang akan menjadi tugas manajemen yang sangat berat yakni bagaimana upaya yang dapat dilakukan manajer agar bawahannya mau bekerja dan berusaha berdasarkan keinginan dan motif berprestasi yang tinggi.Menurut pendapat Pandji Anoraga Motivasi kerja adalah kemauan kerja para karyawan yang terjadi karena adanya dukungan dari dalam diri karyawan yang bersangkutan sebagai hasil dari integrasi keseluruhan daripada kebutuhan pribadi, pengaruh lingkungan fisik dan pengaruh lingkungan sosial dimana kekuatannya tergantung pada proses pengintegrasian karyawan tersebut.

Ernest J. McCormick Motivasi kerja ialah kondisi yang mempengaruhi membangkitkan, mengarahkan, membimbing dan memelihara perilaku yang berhubungan dengan lingkungan kerja karyawan.

Berelson dan Steiner dalam Siswanto Sastrohadiwiryo motivasi kerja adalah Keadaan kejiwaan dan sikap mental 
manusia yang memberikan energi, mendorong kegiatan atau menggerakkan dan mengarah/membimbing perilaku ke arah mencapai kebutuhan yang memberikan kepuasan atau mengurangi ketidakseimbangan.

Motivasi dapat diartikan suatu proses. Pengetahuan mengenai proses yang akan sangat membantu dalam melakukan dan mengamati kelakuan-kelakuan orang tersebut. Motivasi juga dapat diartikan sebagai suatu perbuatan energi dalam diri seseorang yang ditandai dengan timbulnya perasaan dan reaksi untuk mencapai suatu tujuan yang telah ditetapkan.

\section{Menurut Nitisemito} mengemukakan bahwa semangat kerja adalah pekerjaan dilakukan secara baik, lebih giat sehingga pekerjaan dihara dapat diselesaikan lebih cepat dengan produktifitas akan meningkat. Dipertegas oleh Hasibuan (2005:94) bahwa semangat kerja adalah kemauan untuk melakukan suatu pekerjaan dengan tekun dan antusias, sehingga dapat menyelesaikan pekerjaan lebih efektif dan efesien. Selanjutnya Poerwanto (2009:83) menyatakan bahwa semangat kerja adalah reaksi emosioanal dan mental dari seseorang terhadap pekerjaan yang sedang ia jalankan.

Kemudian Sastrohadiwiryo (2002:282), menyatakan bahwa semangat kerja adalah suatu kondisi rohaniah, atau perilaku individu tenaga kerja dan kelompok yang menimbulkan kesenangan yang mendalam pada diri tenaga kerja untuk bekerja dengan giat atau tekun dan konsekuen dalam mencapai tujuan yang ditentukan oleh organisasi.

Berdasarkan pendapat (Ermita, 2012) dapat dikatakan bahwa semangat kerja itu sangat penting dalam mendukung pelaksanaan tugas seseorang dalam bekerja. Semangat kerja menghasilkan suatu kegiatan yang dikerjakan dengan penuh kesadaran tanpa paksaan,sehingga pekerjaan tersebut akan dapat dikerjakan dengan cepat dan tepat.Kinerja karyawan merupakan hasil kerja seseorang dimana seseorang memiliki tanggung jawab yang telah ditetapkan oleh suatu perusahaan untuk memenuhi persyaratan-persyaratan kerja yang telah ditentukan.

Menurut pendapat Mangkunegara (2004) faktor- faktor yang mempengaruhi kinerja karyawan ialah (1).Faktor kemampuan karyawan, seorang pegawai memiliki keterampilan atas pekerjaanya maka pegawai akan lebih mudah mencapai kinerja yang diharapkan oleh instansi. (2).Faktor motivasi,artinya seorang karyawan memiliki keterampilan atas pekerjaanya maka karyawan lebih mudah mencapai kinerja yang diharapkan oleh perusahaan dan motivasi merupakan kondisi yang berpengaruh dalam mengarahkan serta menggerakkan diri para karyawan untuk mencapai tujuan organisasi/perusahaan.

Motivasi mempersoalkan bagaimana caranya mendorong semangat kerja karyawannya, agar mereka dapat dan mau bekerja keras dengan memberikan semua kemampuan dan keterampilanya yang mereka miliki untuk mewujudkan tujuan dari perusahaan yang mereka tempati.

Untuk usaha meningkatkan kinerja pegawainya organisasi melakukan berbagai kebijaksanaan sebagai berikut memberikan motivasi kepada para pegawainya, baik yang bersifat positif seperti pemberian gaji atau upah yang sesuai,mencukupi fasilitas, tempat tinggal,waktu cuti kerja dan lain-lain, ataupun yang bersifat negatif seperti sanksi untuk pegawai yang melanggar peraturan-peraturan, penurunan jabatan dan lain-lain. 
kinerja karyawan dapat berjalan baik apabila ditunjang dengan adanya peran motivasi kerja, seperti karyawan yang mampu menyelesaikan pekerjaanya dengan baik, karyawan memiliki kesadaran yang tinggi terhadap tugas dan tanggung jawabnya dan mentaati peraturan yang telah ditetapkan oleh perusahaan terkait, menciptakan dan menumbuhkan semangat kerja yang tinggi maka perusahaan akan mengalami peningkatan target yang diinginkan. Begitupun sebaliknya jika karyawan tidak mempunyai kesadaran dalam menjalankan tugas dan tanggung jawabnya, kurangnya bersemangat dalam bekerja dengan begitu hasil kinerja kurang maksimal.Tujuan dari penulisan artikel ini adalah untuk mengetahui seberapa besar pengaruh motivasi dan semangat kerja dalam meningkatkan kinerja karyawan di suatu instansi/perusahaan.

\section{METODE PENELITIAN}

Artikel ini disusun dengan metode dan langkah-langkah yang sistematis untuk memudahkan penulis dalam memaparkan hasil penelitian. Pada jurnal ini, peneliti menggunakan metode studi literature dengan cara mengumpulkan literature (bahan-bahan materi) yang bersumber dari buku, jurnal dan sumber lainnya yang berkaitan dengan motivasi dan semangat kerja dalam meningkatkan kinerja karyawan yang peneliti temukan di perpustakaan, artikel dan jurnal yang telah ada. Setelah bahan kajian dikumpulkan, selanjutnya bahan tersebut dipelajari, kemudian penulis berusaha menyimpulkan dan mengenalisis kembali bahan atau kajian yang sudah dikumpulkan.

$\begin{array}{lrr}\text { III KAJIAN } & \text { TEORI DAN } \\ \text { PEMBAHASAN } & & \end{array}$

A. Motivasi
Motivasi merupakan salah satu usaha untuk mempengaruhi karyawan dengan memberikan sesuatu yang diinginkan oleh karyawan agar karyawan dapat bertingkah sesuai dengan apa yang diinginkan oleh pimpinan serta yang lebih penting lagi agar pegawai bersemangat dalam bekerja dan dalam menjalankan tugasnya. (Ningsih \& Jaya, 2016)

Ada tiga unsur dalam motivasi sebagai berikut :

1. Motivasi dimulai dari adanya perubahan energi dalam pribadi. Perubahan-perubahan dalam motivasi timbul dari perubahan-perubahan tertentu dalam sistem neuruphysiologis dalam organisme manusia itu sendiri.

2. Motivasi ditandai oleh munculnya peran affective arousal. Suasana emosi inilah yang menimbulkan kelakuan bermotif. Perubahan ini hanya dapat kita amati pada perbuatan. Seseorang yang terlibat dalam suatu diskusi karena merasa tertarik pada masalah yang akan dibicarakan sehingga dia berbicara dengan bahasa dan kata-kata secara cepat dan tidak ragu-ragu.

3. Motivasi ditandai oleh reaksi-reaksi untuk mencapai suatu tujuan. seseorang yang bermotivasi mengadakan respon-respon yang tertuju pada arah suatu tujuan. Setiap respon merupakan suatu langkah ke arah pencapaian tujuan yang ingin dicapai.

Menurut Hamalik (1992:173), Pengertian Motivasi merupakan perubahan energi dalam diri seseorang yang timbulnya perasaan dan reaksi untuk mencapaisuatu tujuan.

Menurut Sardiman (2006:73), Pengertian Motivasi ialah perubahan energi dalam diri seseorang yang ditandai dengan munculnya felling dan didahului dengan tanggapan dan respon terhadap adanya tujuan. 
Menurut Mulyasa (2003:112), Pengertian Motivasi merupakan kekuatan pendorong atau penarik yang menyebabkan adanya tingkah laku ke arah suatu tujuan tertentu. Peserta didik akan bersungguh-sungguh karena memiliki motivasi yang sangat tinggi.

Menurut Victor H. Vroom, motivasi adalah sebuah akibat dari suatu hasil yang ingin dicapai oleh seseorang dan sebuah perkiraan bahwa apa yang dilakukannya akan mengarah pada hasil yang diinginkan oleh perusahaan.

Dari pengertian diatas maka dapat disimpulkan bahwa motivasi adalah suatu keadaan atau kondisi yang mendorong, menggerakan seseorang untuk melakukan suatu kegiatan yang dilakukannya sehingga seseorang dapat mencapai tujuannya.

Adapun fungsi dari motivasi adalah sebagai berikut.

1. Mendorong timbulnya tindakan atau suatu perbuatan. Tanpa motivasi tidak akan timbul suatu perbuatan atau tindakan.

2. Motivasi berfungsi sebagai pengarah, artinya mengarahkan perbuatan untuk mencapai tujuan yang diinginkan.

3. Motivasi berfungsi sebagai penggerak. Besar atau kecilnya motivasi akan menentukan cepat atau lambatnya seseorang dalam menyelesaikan suatu pekerjaan.

Ada beberapa cara yang dapat dilakukan oleh seorang pimpinan untuk meningkatkan motivasi kerja dari karyawannya sebagai berikut:

\section{Berikan Inspirasi}

Semua pemimpin yang hebat mampu untuk menginspirasi karyawannya. Berikan pandangan jauh ke depan mengenai bisnis dan perusahaan yang bisa dicapai dengan berkaca terhadap kesuksesan bisnis lain misalnya dengan demikian dapat menimbulkan minat dari karyawan.

\section{Berikan mereka Kesempatan}

Ada begitu banyak anggapan bahwa micromanagement akan menghambat kreativitas dan membunuh motivasi. Dengan demikian, berikan karyawan Anda kesempatan dan "kekuatan" untuk mengekspresikan diri mereka. Mulailah dari hal yang sangat sederhana seperti menerima dan menjalankan salah satu masukan yang disampaikan oleh karyawan.

\section{Tetapkan Tujuan yang ingin dicapai.}

Semua orang sangat membutuhkan tujuan pribadi agar mampu konsisten dan loyalitas dalam mnejalankan sesuatu tanggung jawab demi mencapai tujuan itu. Coba berikan mereka tujuan jelas yang akan mereka capai (misalnya tujuan jalan-jalan dalam negeri dan luar negeri, rumah, benda fisik dan lain-lain)

4. Jangan Terlalu Mengkritik Kesalahan

Tidak semua kesalahan sama. Kecerobohan dan kelalaian memang perlu segera diatasi, namun jika kesalahan tersebut terjadi setelah karyawan sudah bekerja sangat keras, maka pujilah (hargailah) usaha mereka. Jika kerja keras mereka tidak dihargai maka sama saja dengan Anda membunuh dan mematahkan kreativitas, inovasi dan inisiatif karyawan.

\section{Berikan Penghargaan}

Walaupun sederhana, namun cara ini harus dilakukan oleh setiap pimpinan. Banyak penelitian menunjukkan bahwa salah satu hal terbaik yang dapat Anda lakukan terhadap karyawan ialah mengenali dan menghargai usaha mereka dengan mengatakan terima kasih ketika mereka melakukan sesuatu yang baik dan berguna. Jelaskan secara 
spesifik mengenai prestasi yang telah mereka capai.

\section{Berikan Feedback yang Membangun}

Karyawan memerlukan feedback positif untuk dapat merasa termotivasi, namun mereka juga membutuhkan feedback negatif yang disampaikan secara konstruktif karena ini akan menunjukkan bahwa Anda sangat peduli terhadap mereka dan tidak meninggalkan mereka disaat keadaan sulit.

7. Sampaikan Perkembangan dan kemajuan Bisnis

Ciptakan rasa urgensi yang lebih besar kepada karyawan dengan cara memberikan informasi mengenai perkembangan dan kemajuan bisnis khususnya dalam aspek keuangan. Biarkan mereka merasa khawatir mengenai keuangan perusahaan dan motivasi mereka untuk bekerja lebih keras lagi agar keuangan perusahaan stabil dan bisa memberikan bonus bagi kepada karyawan.

\section{Berikan Reward Bagi Karyawan yang Berprestasi}

Coba untuk memberikan bonus dari keuntungan perusahaan kepada karyawan. Dengan begitu mereka akan terus termotivasi untuk semakin meningkatkan kinerjanya

9. Jangan Biarkan Karyawan Bekerja di Luar Kemampuan yang mereka miliki.

Jangan terlalu memaksakan sesuatu pekerjaan kepada karyawan jika ia tidak sanggup, baik dalam hal jam kerja atau bobot pekerjaannya. Pahamilah kemampuan dan kehidupan lain mereka di luar kantor, jika tidak maka akan mengakibatkan produktivitas karyawan akan menurun.

10. Berikan Perhatian
Karyawan perlu untuk merasa kehadirannya di perusahaan penting, mereka harus tahu bahwa posisi dan hasil pekerjaan mereka sangat dibutuhkan oleh perusahaan. Pastikan manajer senior dan CEO memberikan perhatian kepada karyawan tersebut.

\section{B. Semangat kerja}

Menurut Nitisemito (1999:12) bahwa semangat kerja adalah pekerjaan yang dilakukan secara baik, lebih giat sehingga pekerjaan diharapkan dapat diselesaikan lebih cepat dengan produktifitas akan meningkat. Dipertegas oleh Hasibuan (2005:94) bahwa semangat kerja adalah kemauan untuk melakukan suatu pekerjaan dengan tekun dan antusias, sehingga dapat menyelesaikan pekerjaan lebih efektif dan efesien.

Selanjutnya Poerwanto (2009:83) menyatakan bahwa semangat kerja adalah reaksi emosioanal dan mental dari seseorang terhadap pekerjaan yang sedang ia jalankan.

Kemudian Sastrohadiwiryo (2002:282), menyatakan bahwa semangat kerja adalah suatu kondisi rohaniah, atau perilaku individu tenaga kerja dan kelompok yang menimbulkan kesenangan yang mendalam pada diri tenaga kerja untuk bekerja dengan giat atau tekun dan konsekuen dalam mencapai tujuan yang ditentukan oleh organisasi.

Berdasarkan pendapat (Ermita, 2012) dapat dikatakan bahwa semangat kerja itu sangat penting dalam mendukung pelaksanaan tugas seseorang dalam bekerja. Semangat kerja menghasilkan suatu kegiatan yang dikerjakan dengan penuh kesadaran tanpa paksaan,sehingga pekerjaan tersebut akan dapat dikerjakan dengan cepat dan tepat.Kinerja karyawan merupakan hasil kerja seseorang dimana seseorang memiliki 
tanggung jawab yang telah ditetapkan oleh suatu perusahaan untuk memenuhi persyaratan-persyaratan kerja yang telah ditentukan.

Ada beberapa alasan pentingnya semangat kerja bagi organisasi atau perusahaan sebagai berikut

1. Dengan adanya semangat kerja yang tinggi dari karyawan maka pekerjaan yang diberikan kepadanya dapat diselesaikan dengan waktu yang lebih singka tdan lebih cepat.

2. Dengan semangat kerja yang tinggi, tentunya dapat menurunkan angka absensi (bolos) atau tidak bekerja karena alasannya malas.

3. Dengan semangat kerja yang tinggi, pihak organisasi atau perusahaan juga akan memperoleh keuntungan dari sudut kecilnya angka kerusakan, karena seperti diketahui bahwa semakin tidak puas dalam bekerja, semakin tidak bersemangat dalam bekerja, maka semakin besar pula angka kerusakan yang akan terjadi.

4. Dengan semangat kerja yang tinggi, pasto membuat karyawan akan merasa nyaman dalam bekerja, dengan demikian kecil kemungkinan karyawan tersebut akan pindah bekerja ketempat yang lain, dengan hal inilah berarti semangat kerja yang tinggi akan dapat menekan angka perpindahan tenaga kerja atau labour turn over.

5. Dengan semangat kerja karyawan yang tinggi akan mengurangi angka kecelakaan, karena karyawan mempunyai kecenderungan bekerja dengan kehati-hatian dan teliti, sehingga sesuai dengan prosedur kerja yang ada diorganisasi atau persahaan sebelumnya.

C. Kinerja karyawan

Dalam Kamus Bahasa Indonesia dikemukakan arti kinerja sebagai
“(1) sesuatu yang telah dicapai; (2) prestasi yang diperlihatkan; kemampuan kerja seseorang"

Menurut Para Ahli

Bernardin dan Russel (dalam Ruky, 2002:15) memberikan pandangan bahwa kinerja adalah : "performance is defined as the record of outcomes produced on a specified job function or activity during time period. Prestasi atau kinerja adalah catatan tentang hasil-hasil yang diperoleh dari fungsi-fungsi pekerjaan tertentu atau kegiatan selama kurun waktu tertentu.

Berdasarkan pendapat (Purnama, 2008) kinerja dan prestasi kerja dapat disimpulkan bahwa pengertian kinerja maupun prestasi kerja mengandung substansi pencapaian hasil kerja oleh seseorang dalam bekerja. Dengan demikian bahwa kinerja merupakan cerminan hasil yang dicapai oleh seseorang atau sekelompok orang.

Salah satu faktor yang mempengaruhi kinerja karyawan adalah motivasi dimana suatu kondisi yang berpengaruh mendorong serta mengarahkan dan menggerakkan diri pegawai yang terarah untuk mencapai tujuan dari organisasi. Menurut pandangan Wirawan (2009) juga mengemukakan bahwa kinerja yang rendah dapat disebabkan oleh faktor manusia salah satunya adalah motivasi kerja dari seseorang. Dengan motivasi kerja yang tinggi karyawan akan lebih giat dan tekun lagi dalam menyelesaikan tugas dan tanggung jawabnya dan sebaliknya dengan motivasi yang rendah karyawan akan mudah menyerah, merasa malas dan mudah putus asa.

D. Hubungan motivasi dan semangat kerja dalam meningkatkan kinerja karyawan

Hubungan motivasi dan semangat kerja yaitu adanya motivasi kerja pada karyawan akan mendorong 
meningkatkan suatu kinerja karyawan dimana motivasi kerja yang tinggi akan memberikan dampak positif bagi diri sendiri maupun bagi perusahaan. Motivasi kerja menjadi suatu hal yang amat penting dalam mewujudkan kinerja yang berkualitas. Karyawan yang memiliki motivasi kerja yang tinggi akan membawa dampak positif bagi perusahaan dalam pencapaian tujuan dari instansi atau organsasi tersebut. Dan semangat kerja juga sangat penting dalam mendukung pelaksanaan tugas seseorang dalam bekerja. Semangat kerja menghasilkan suatu kegiatan yang dikerjakan dengan penuh kesadaran tanpa paksaan,sehingga pekerjaan tersebut akan dapat dikerjakan dengan cepat dan tepat dan sesuai dengan yang diharapkan oleh instansi terkait.

Dengan motivasi yang tinggi dan semngat kerja yang begitu tinggi dari karyawan akan berdampak sangat positif bagi kinerja seseorang dalam suatu perusahaan tersebut.

\section{Kesimpulan dan Saran}

Berdasarkan beberapa sumber yang penulis temukan maka dapat ditarik kesimpulan bahwa terdapat hubungan yang positif antara motivasi,semangat kerja dalam meningkatkan kinerja karyawan di suatu perusahaan. Semakin tinggi motivasi dan semangat kerja karyawan maka semakin baik pula kinerja karyawan di suatu perusahaan hal ini juga akan berdampak baik bagi keberlansungan perusahaan untuk kedepannya dan tujuan-tujuan sudah direncanakan sebelumnya akan tercapai secara efektif dan efesien dan sebaliknya apabila semakin rendah motivasi dan semangat karyawan makan semakin buruk kinerja dari karyawan tersebut dan akan berakibat buruk untuk perusahaan kedepannya.

Saran yang dapat penulis sampaikan pada jurnal ini adalah sebaiknya seorang pimpinan mampu menumbuhkan dan meningkatkan semangat dan motivasi karyawan dalam bekerja karena dengan tingginya motivasi dan semangat karyawan dalam bekerja akan berdampak positif bagi instansi atau perusahaan tersebut.

\section{Daftar Pustaka}

Ermita. (2012). Hubungan Antar Manusia dan Semangat Kerja Pegawai. Jurnal Ilmiah Ilmu Pendidikan, XII(2), 70-81.

Ningsih, S., \& Jaya, I. (2016). Hubungan Motivasi Kerja Dengan Kinerja Karyawan Pada PT KAO Indonesia. Jurnal Ilmiah Manajemen Fakultas Ekonomi, 2(1), 20-29.

Purnama, R. (2008). Penagaruh Motivasi Terhadap Produktivitas Karyawan Produksi CV . Epsilon Bandung. Jurnal Strategic, 7(14), 58-82. https://doi.org/10.1109/IGARSS.20 13.6723489 